\title{
WestVirginiaUniversity
}

THE RESEARCH REPOSITORY @ WVU

West Virginia Agricultural and Forestry Experiment

Davis College of Agriculture, Natural Resources

Station Bulletins

And Design

$1-1-1978$

\section{Dependence on credit by rural and urban retail firms}

William C. St. Clair

Ernest J. Nesius

Follow this and additional works at: https://researchrepository.wvu.edu/ wv_agricultural_and_forestry_experiment_station_bulletins

\section{Digital Commons Citation}

St. Clair, William C. and Nesius, Ernest J., "Dependence on credit by rural and urban retail firms" (1978). West Virginia Agricultural and Forestry Experiment Station Bulletins. 662.

https://researchrepository.wvu.edu/wv_agricultural_and_forestry_experiment_station_bulletins/562 @ WVU. It has been accepted for inclusion in West Virginia Agricultural and Forestry Experiment Station Bulletins by an authorized administrator of The Research Repository @ WVU. For more information, please contact ian.harmon@mail.wvu.edu. 


\section{Dependence On Credit By Rural and Urban \\ Retail Firms}
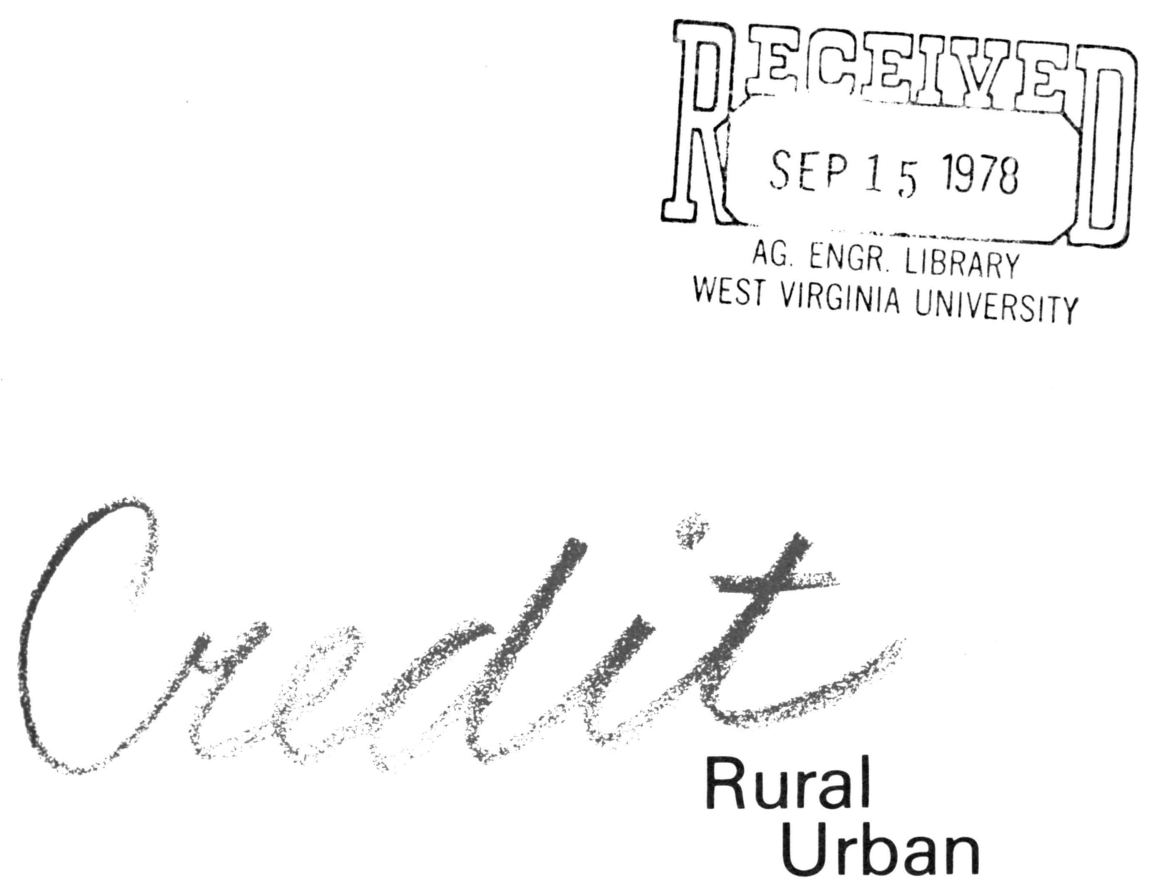

S127

- EI

No. 662

Bulletin 662

March 1978

West Virginia University

Agricultural and Forestry Experiment Station 


\section{AUTHORS}

William C. St. Clair was a graduate student in Resource Management and Ernest J. Nesius was Benedum Professor of Agricultural Economics and Agricultural Economist.

\section{ABSTRACT}

Use of credit and reasons for not using it in the operation of a retail business was studied. Ten factors were found to be statistically significant when related to the degree of credit use by retail firms in financing two dependent variables considered to be a most important measure of dependency. Rural and urban retail firms were compared. Risk aversion was evaluated.

\section{Key Words}

Credit, rural, urban, areas, agriculture, mining, industrial, retail, firms, factors, risk, and central place.

West Virginia University Agricultural and Forestry Experiment Station

College of Agriculture and Forestry

Dale W. Zinn, Director Morgantown 


\section{CONTENTS}

Summary and Conclusions . . . . . . . . . . . . . . iii

Procedure . . . . . . . . . . . . . . . 2

Differences Between Rural and Urban Retail Business Firms . . . 7

Factor 1: Classes of Retail Business . . . . . . . . . . . . . . . 8

Factor 2: Assets . . . . . . . . . . . . . . . . 9

Factor 3: 1974 Sales Volume . . . . . . . . . . . . . . . . . . 9

Factor 4: Average Monthly Inventory Purchases . . . . . . . . 10

Factor 5: Average Monthly Business Expenses . . . . . . . . 10

Factor 6: Total Liabilities . . . . . . . . . . . . . . . . . 12

Factor 7: Mean Asset to Liability Ratio . . . . . . . . . . . . . 12

Factor 8: Average Age of Business Firms . . . . . . . . . . . 12

Factor 9: Average Number of Full-Time Employees . . . . . . . 14

Factor 10: Form of Organization . . . . . . . . . . . . . . . 14

Factor 11: Building Ownership . . . . . . . . . . . . . . 14

Factor 12: Credit Sales . . . . . . . . . . . . . . . . 14

Factor 13: Industry Characteristics . . . . . . . . . . . . . . 15

Multiple Regression Analysis of Selected Variables . . . . . . . . 15

Percent of Monthly Inventory Purchase -

Externally Financed-Dependent Variable 1 . . . . . . . . . . . 17

Percent of Business Expansion Expenses Externally

Financed Since 1960-Dependent Variable 2 . . . . . . . . . . . 17

Regional Differences Explained by Environmental Factors Which Influence Rural Entrepreneurs' Use of Credit . . . . . . . . . . . 18 Bibliography . . . . . . . . . . . . . . . . 19

Appendix ..................... 20 
Blank Page in Original Bulletin 


\section{SUMMARY AND CONCLUSIONS}

The purpose of this study was to determine if there was a relationship between the population size of central places and the utilization of credit by firms located in them. More specifically, the objectives were to determine if rural business firms were depending on credit to a lesser or greater extent than urban firms if capital rationing was imposed by lenders, variability in the characteristics of retail firms in different size interval central places and the reasons for the lack of use of credit, if evident.

The data were obtained through personal interviews with owners or managers of 571 retail business firms in 138 central places in six counties. (See Appendix for sample questionnaire.)

Analysis of the data, which was for the period 1960-1975, indicated that as the population of the central place increased, the dependence of retail firms on credit also increased. Of the five major retail credit sources, rural firms depended on the Small Business Administration, friends and relatives to a greater extent that did the urban firms. The dependence on the Small Business Administration was affected by the Buffalo Creek flood disaster in Logan County in 1973.

That rural firms were less dependent on credit was offset somewhat by their greater dependence on self-financing for major expenditures. As the size of the central places increased, the average amount of business expansion expenses and inventory purchases that were self-financed by the business firms decreased.

External capital rationing was not found to be the reason for rural businesses' lack of use of credit. Only 8 percent of the firms had been refused loans from institutional lenders and this was not statistically significantly different among the central places of varying size.

Two multiple regression equations were used to determine the relationships of thirteen factors to the firms' dependence on external financing-percent monthly inventory. purchases externally financed, which explained 30 percent of the variance; and percent business expansion expenses externally financed since 1960, which explained 29 percent. Ten factors were found to be significant in influencing the retail firms' dependence on external financing: (1) the 1974 sales volume of the businesses, (2) classes of retail firms, (3) the average monthly inventory purchases of the firms, (4) age of retail firms, (5) ownership of buildings in which they operated, (6) number of full-time employees, (7) liabilities of the firms, (8) ratio of assets to liabilities, (9) kinds of business organization, and (10) industry characteristics of the trade area.

The major findings of this study indicated that the generally uncontrollable factors of size, type of business, and age were the major reasons rural firms were less dependent on credit. But, rural firms' lack of credit use, their greater dependence on friends and relatives as credit sources, and their high ratios of assets to liabilities suggested they preferred to avoid the risks involved with borrowing. Contributing to these attitudes were the local attitudinal factors influencing their value patterns and feelings toward credit. As external factors influence local attitudes they will be reflected in the decisions of rural people toward credit. 
Blank Page in Original Bulletin 


\section{Dependence on Credit by}

\section{Rural and Urban Retail Firms}

\section{William C. St. Clair and Ernest J. Nesius}

Firms in small rural towns survive because of the basic goods and services they provide to the residents in and within driving distance of the towns. Many of these firms have been forced to close due to population migration to larger central places. ${ }^{1}$ The economic problems associated with the migration have caused federal and state governments to be deeply concerned (20). The remaining small retail firms do provide a foundation upon which to stimulate rural economic development and thus they are important to the nation's economy. They provide income and employment, pay local property taxes, and provide the personal interest of a small entrepreneur in the development of his community, a characteristic rarely found in the larger central places (20).

It is believed that one need of the small firm is credit. Government and other reports recognize the importance of credit in the operations of small firms (15; $16 ; 21 ; 10)$. These studies recognize that the inability of firms to obtain credit at favorable interest rates is only one of their financial problems. Other important problems may relate to the managerial experience of entrepreneur $(19 ; 7)$ or his reluctance to use credit.

The general purpose of this study, carried out in 1975, was to determine if a relationship exists between the population size of central places and the extent to which credit is provided and/or utilized by retail firms located in them. The specific objectives were:

1. To determine if retail firms in rural central places depend upon credit to a lesser or greater extent than retail firms in urban central places.

2. To determine if lenders rationed credit based upon size of central place.

3. To determine the types of retail firms found in different size central places.

4. To determine reasons for the lack of use of credit if evident.

An understanding of the differences in the use of credit between rural and urban firms could provide policy guidelines for helping to stabilize and strengthen the economic position of firms in rural areas, assuming that such would be desirable.

\footnotetext{
${ }^{1}$ Central places will cover all classifications of population concentration; e.g., stringtown, clusters of dwellings, hamlet, town, and cities.
} 
Reluctance to use borrowed capital to support a continuing or expanding business is usually attributed to: (1) risk aversion, in which the firm's manager psychologically discounts future returns at a high rate determined by his un. willingness to deal with uncertainty; (2) the probability of social stigma as. sociated with indebtedness, which is usually attributed to the system of values in: the local community; and (3) capital rationing carried out by the lender for one or more reasons.

Studies by Colyer (5) and Knight (11) confirmed the influence of risk aversion. , Rogers (17) and Hollander (9) discussed the influence of social stigma. Within the three types of economic environments, the findings of this study reinforce the conclusions of these writers.

Capital rationing, ${ }^{2}$ the third cause for inadequate use of credit, is assumed to be largely the response of lending firms to their interpretations of uncertainty and their evaluation of the potential risk position of the individual borrower whose motives for borrowing are governed somewhat by risk aversion and social stigma.

\section{PROCEDURE}

There are approximately 1,786 populated central places in West Virginia. Of these 234 are municipalities and only 17 have a population greater than 10,000 (13). Because West Virginia is one of the most rural states in the United States, and because economic development is a major statewide program activity, this study is of particular significance to rural economic development. (See Figure 1 for the study areas.)

To satisfy the purpose and objectives of the study, established trade areas were chosen to represent low, median, and high rates of economic development. To identify the trade areas, indicators supportive of economic development were used-income per capita, percent of families with income less than $\$ 3,000$, index of economic development, percent rural population, and bank deposits per capita. These data were obtained from a U. S. Department of Agriculture trading area study for 1960 (6). In that report each of the indicators were ranked from the highest (number 1) to the lowest (number 500) for each of more than 500 trading areas. West Virginia trading areas falling in the high 50 , the middle 50 , and the bottom 50 were given further attention to determine which were most typical for the top, median, and bottom groups. The West Virginia trading areas ranked most often in each of the three categories of 50 were considered as most typical of the group. As it turned out this method identified the areas of high, median, and low urbanization and income. From this list the Steubenville,

${ }^{2}$ Capital rationing as interpreted here refers to the willingness of a lender to loan to an applicant. It is recognized that individual business firms do ration the funds they are willing to borrow. There is reflected under the references to risk and uncertainty as viewed by the business firm. 


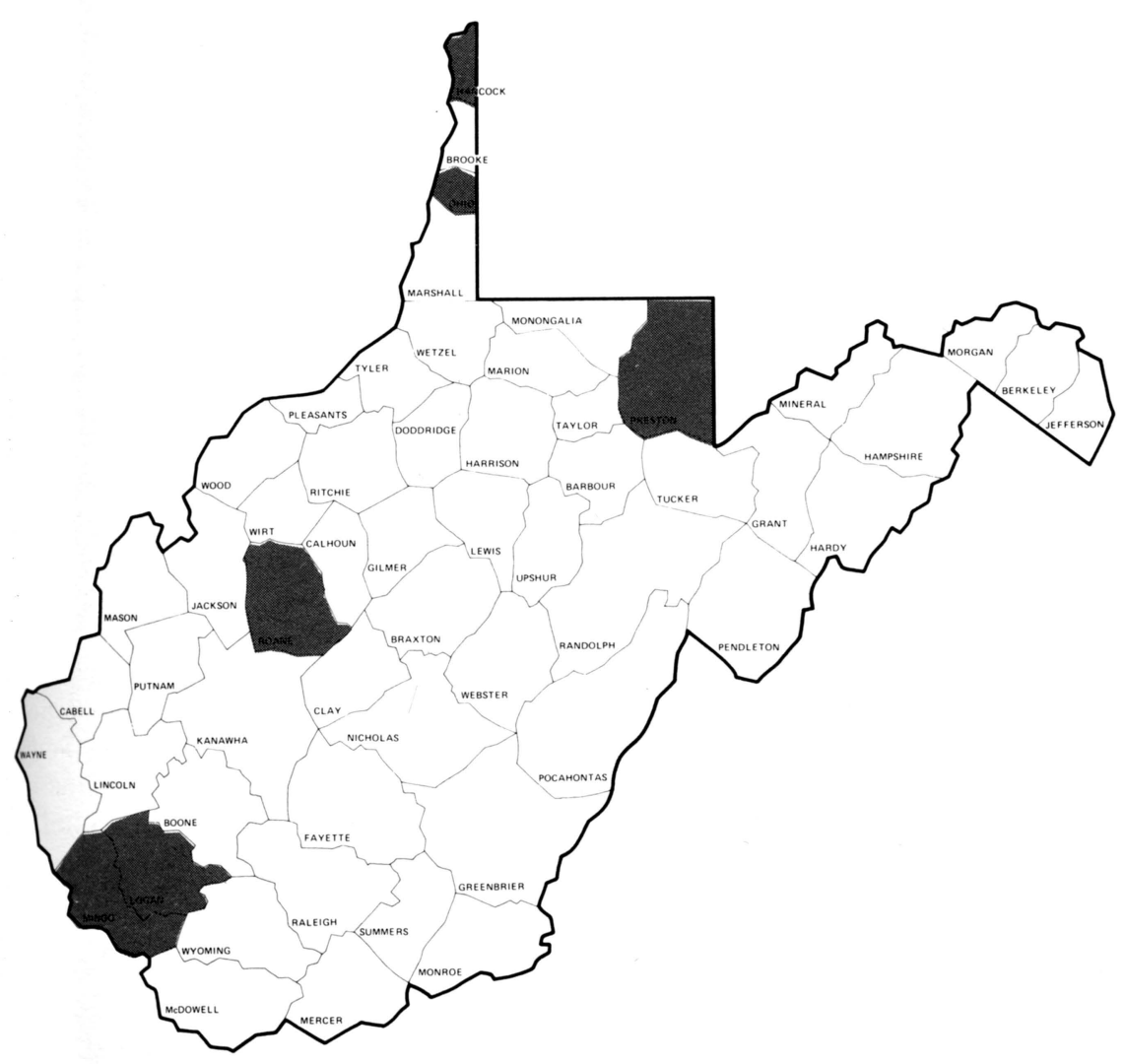

FIGURE 1. The Study Areas, West Virginia

Ohio/Weirton and Wheeling trading area covering the West Virginia counties of Hancock and Ohio represented the regions of greatest urbanization and income (hereafter called Industrial Sample). The Pikeville, Kentucky/Logan, West Virginia trading area covering Logan and Mingo counties represented the regions of lower income and urbanization (hereafter called Mining Sample). In the middle or median group Preston and Roane counties were selected to be most representative $^{3}$ (hereafter called Agricultural Sample) (Figure 1).

${ }^{3}$ Preston and Roane are not in the same trade areas but comparisons as to similiarity justified using them as a combination. 
Central places were sorted into five population size groups ${ }^{4}$ in order to establish a method for recognizing the differences between the retail firms.

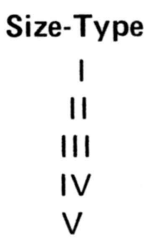

\section{Population}

Less than 400

$400-1,199$

$1,200-2,499$

$2,500-9,999$

10,000 and more

Because information on retail firms by size of central place was almost nonexistent from secondary sources, the needed information had to be obtained through personal interviews (see Appendix for the questionnaire). Inability to obtain estimates of the parameters needed to determine the proper sample size led to drawing a sample that was believed to be representative of the population of the six counties. A pre-survey estimate of sample size suggested 105 completed schedules were to be required for each size-type of central place, or a total of 525 completed schedules. The guideline for providing estimates on the number of schedules needed was found in two threshold population studies $(4 ; 3)$.

A further breakdown of the estimated required schedules is as follows:

Size-Type of
Central Place
(Size Classification)
I
II
III
IV
V

Size-Type of

Central Place

\section{Estimated Number \\ of Firms for Each \\ Central Place}

1

4.5

35

large number

large number

\section{Number of Central Places to $\mathrm{Be}$ Randomly Selected}

105

25

3

3

2

${ }^{4}$ The size groupings were chosen keeping in mind population numbers and the purchasing power necessary to support a retail business. A population of less than 400 is considered minimum for supporting the retail firms which supply household basic goods. A population range of 400-1,199 was considered the minimum for more of the basic retail services needed at a central place. The population range of 1,200-2,499 was chosen because a population level of less than 2,499 is the lowest classification to be called rural by the Bureau of Census. 
The unequal number of central places by population intervals required to meet the sample requirements is shown in Table 1.

A total of 616 firms were contacted and 571 completed schedules were obtained (Table 2).

TABLE 1. Distribution of central places by trading areas and type of central place to meet the sample requirements

\begin{tabular}{cccc}
\hline \hline & \multicolumn{3}{c}{ Number of Central Places } \\
\cline { 2 - 4 } Type Central Place & $\begin{array}{c}\text { Industrial } \\
\text { Sample }\end{array}$ & $\begin{array}{c}\text { Agricultural } \\
\text { Sample }\end{array}$ & $\begin{array}{c}\text { Mining } \\
\text { Sample }\end{array}$ \\
\hline I & 5 & 61 & 92 \\
II & 5 & 5 & 47 \\
III & 4 & 1 & 8 \\
IV & 1 & 2 & 2 \\
V & 2 & 0 & 0 \\
Total & 17 & 69 & 149 \\
\hline
\end{tabular}

Source: West Virginia Department of Commerce, Planning and Research Division, West Virginia Incorporated and Unincorporated Communities (revised second edition, Charleston, West Virginia: 1967) pp. 2-24.

TABLE 2. Total firms contacted, number of completed schedules and refusals by type of central place

\begin{tabular}{|c|c|c|c|}
\hline Type Central Place & $\begin{array}{c}\text { Total } \\
\text { Firms } \\
\text { Contacted }\end{array}$ & $\begin{array}{l}\text { Completed } \\
\text { Schedules }\end{array}$ & Refusals \\
\hline I & 125 & 112 & 13 \\
\hline II & 129 & 119 & 10 \\
\hline III & 112 & 104 & 8 \\
\hline IV & 121 & 111 & 10 \\
\hline V & 129 & 125 & 4 \\
\hline Total & 616 & 571 & 45 \\
\hline
\end{tabular}


Selection of the counties as typical for three levels of economic development resulted in three study regions with three different types of economic activity-in Ohio and Hancock counties, where economic development is presumed to be progressing at the highest rate because of the higher level of income and urbanization-manufacturing is dominant; in Preston and Roane counties with middle income and urbanization-agriculture, though not dominant, is important; and in Logan and Mingo counties-mining is dominant. Comparison of the proportions of persons employed in manufacturing, agriculture, and mining industries reinforced this relationship (Table 3). Thus three of the states' major industry types were represented in the study.

The three typical situations selected henceforth will be identified as Industrial Counties, Agricultural Counties, and Mining Counties. The agricultural counties are not dependent on agriculture as their major income source, but agriculture there is more important than it is in the other counties.

As another way to view the selection of the three trading areas, sales volume and proportion of rural sales volume to the total were calculated for retail firms. Sales per firm and percent of retail firms considered non-rural were higher in the industrial counties. The agricultural and mining counties, on the other hand, showed almost the same relationships on percent of retail firms considered rural and 1967 sales per firm. In the mining counties, the percent of rural sales volume to the total was considerably higher (Table 4).

TABLE 3. Comparison of the proportion of the total labor force in manufacturing, agriculture, and mining to the state average by counties in the trade areas

\begin{tabular}{lrrrrrrr}
\hline \hline \multirow{2}{*}{$\begin{array}{l}\text { Industry } \\
\text { Category }\end{array}$} & \multirow{2}{*}{$\begin{array}{c}\text { State } \\
\text { Average }\end{array}$} & Ohio & Hancock & Preston & Roane & Logan & Mingo \\
\cline { 3 - 8 } & $\%$ & $\%$ & $\%$ & $\%$ & $\%$ & $\%$ & $\%$ \\
Manufacturing & 23.09 & 24.74 & 54.66 & 23.59 & 24.06 & 7.09 & 6.33 \\
Agriculture & 2.10 & .94 & .82 & 4.53 & 2.92 & .45 & .84 \\
Mining & 8.75 & 3.37 & .69 & 13.13 & 4.97 & 32.53 & 24.11 \\
& & & & & & & \\
\hline
\end{tabular}

Source: Dale Colyer, West Virginia Employment by Industry Category (Resource Management Series No. 13. Morgantown, West Virginia: West Virginia University, 1973) pp. 10-58. 
TABLE 4. Total number of retail firms, 1967 sales, total number of rural retail firms, and percent of total sales volume belonging to rural retail firms by trade areas

\begin{tabular}{lccc}
\hline \hline & $\begin{array}{c}\text { Industrial } \\
\text { Trade Area }\end{array}$ & $\begin{array}{c}\text { Agricultural } \\
\text { Trade Area }\end{array}$ & $\begin{array}{c}\text { Mining } \\
\text { Trade Area }\end{array}$ \\
\hline $\begin{array}{l}\text { Total number of } \\
\text { retail firms }\end{array}$ & 904 & 379 & 791 \\
$\begin{array}{l}1967 \text { sales }(\$ 1,000) \\
\begin{array}{l}1967 \text { sales per retail } \\
\text { firm }(\$ 1,000)\end{array}\end{array}$ & 180,258 & 44,265 & 91,707 \\
$\begin{array}{l}\text { Percent of all retail } \\
\text { firms considered rural }\end{array}$ & 199 & 116 & 116 \\
$\begin{array}{l}\text { Percent rural sales } \\
\text { volume of the total }\end{array}$ & 9 & 67 & 68 \\
\hline
\end{tabular}

Source: United States Department of Commerce, Bureau of Census, Census of Business: 1967. Retail Trade Area Statistics, Vol. I/ (Washington: U. S. Government Printing Office, 1970) pp. 504-50.

\section{DIFFERENCES BETWEEN RURAL AND URBAN RETAIL BUSINESS FIRMS}

Interviews with several lending firms prior to taking the field interviews revealed that capital rationing was one of the major factors affecting the use of borrowed capital by business firms. Therefore, a section on refusal by lenders was included in the questionnaire. The percentage of business firms refused credit from lenders in all five types of central places was not found to be significantly different (Table 5). This relationship suggests that capital rationing by lenders did not explain why rural business firms borrowed less often than their urban counterparts.

The extent to which firm financing is done from external sources or savings is generally a good indicator of the attitude toward risk of indebtedness. It was found that urban business firms were more dependent on external financing for inventory purchases and business expansion expenses ${ }^{5}$ (Table 6). With an increase in interval size of the central places (Size-type I to V), the percent of

\footnotetext{
${ }^{5}$ Expenses of the firms were grouped into three categories, business, inventory, and expansion. Business expenses were defined as expenditures for such things as rent, utilities, and salaries; inventory expenses included all expenditures for goods purchased for resale; and expansion expenses were defined as capital expenditures for fixed assets such as land, building, and equipment.
} 
self-financed monthly inventory purchases decreased as did the percent self-financed business expansion. Thus rural central place business firms tended to finance inventory purchases and expansion from internal sources to a greater extent than did the urban firms.

TABLE 5. Percentage of business firms refused credit since 1960 by type of central place

\begin{tabular}{lccccr}
\hline \hline & \multicolumn{5}{c}{ Type } \\
\cline { 2 - 6 } & I & II & III & IV & V \\
\hline $\begin{array}{l}\text { Percentage of firms } \\
\text { refused credit }\end{array}$ & 8.0 & 7.7 & 6.7 & 5.4 & 8.0 \\
\hline
\end{tabular}

Results $x^{2}$ : @ = .01 d.f. $=4$. Computed $x_{c}^{2}=1.27$. Theoretical $x_{t}^{2}=9.98$ accept Ho: $n_{1}=n_{2}=n_{3}=n 4=n_{5}$ where $X^{2}$ is the Chi square statistic.

TABLE 6. Percentage of monthly inventory purchases self-financed and business expansion expenses self-financed since 1960 by size-type of central place

\begin{tabular}{lccccc}
\hline \hline & \multicolumn{5}{c}{ Size-Type } \\
\cline { 2 - 6 } & I & II & III & IV & V \\
\hline $\begin{array}{l}\text { Monthly inventory } \\
\text { self-financed }\end{array}$ & 72.3 & 65.8 & 62.5 & 41.7 & 27.8 \\
$\begin{array}{c}\text { Business expansion } \\
\text { expenses self-financed }\end{array}$ & 84.3 & 85.4 & 71.4 & 61.3 & 59.0 \\
\hline
\end{tabular}

Preliminary analysis of the data showed thirteen factors which might explain ways in which rural firms differed from urban firms.

\section{Factor 1: Classes of Retail Businesses}

Using the Standard Retail Classes, ${ }^{6}$ food stores and gasoline service stations were dominant in size-type I. Food stores, auto stores, gasoline service stations, furniture and home furnishings stores, and eating and drinking places were dominant in size-types II and III. The classes of retail business firms in size-types IV and $\mathrm{V}$ were similar to those in size-types II and III, but there was evidence of more diversification in classes of firms (Table 7).

\footnotetext{
${ }^{6}$ This refers to the classification used by the Bureau of Census which categorizes firms according to the commodity group which was the primary source of receipts.
} 
TABLE 7. Percentage of business firms by size-type of central place and standard retail classification

\begin{tabular}{|c|c|c|c|c|c|}
\hline \multirow[b]{2}{*}{ Industry Classification } & \multicolumn{5}{|c|}{ Size-Type } \\
\hline & 1 & II & III & IV & V \\
\hline Building material dealers & 6.3 & 4.2 & 2.9 & 5.5 & 4.8 \\
\hline General merchandise stores & 6.3 & 5.9 & 7.7 & 9.1 & 0.8 \\
\hline Food stores & 39.3 & 21.8 & 19.2 & 24.3 & 11.2 \\
\hline Auto stores & 8.9 & 10.9 & 5.8 & 10.8 & 14.2 \\
\hline Gasoline service stations & 19.6 & 19.3 & 18.3 & 11.7 & 9.6 \\
\hline Apparel and accessory stores & 0.0 & 1.7 & 7.7 & 5.4 & 7.2 \\
\hline $\begin{array}{l}\text { Furniture and home } \\
\text { furnishing stores }\end{array}$ & 4.5 & 10.1 & 12.5 & 4.5 & 12.8 \\
\hline Eating and drinking places & 4.5 & 16.8 & 11.5 & 14.4 & 17.6 \\
\hline Drug and proprietary stores & 1.8 & 1.7 & 2.9 & 4.5 & 1.6 \\
\hline Miscellaneous retail stores & 8.0 & 7.6 & 10.6 & 9.9 & 18.4 \\
\hline Non-store retailers & 0.8 & 0.0 & 0.9 & 0.0 & 1.6 \\
\hline Total & 100.0 & 100.0 & 100.0 & 100.0 & 100.0 \\
\hline
\end{tabular}

\section{Factor 2: Assets}

Firms were grouped according to their asset structure into ten classes (Table 8). In size-type I (population less than 400) the value of the asset structure was significantly less but more diverse than the other four size-type classifications, with a fairly even distribution in numbers with assets between $\$ 5,000$ and $\$ 74,000$. For size-types II, III and IV, the average size was similar with a tendency for firms to be larger as the population size interval increased. For size-type $\mathrm{V}$ the jump in asset size was large, as would be expected, and as determined by a weighted mean. ${ }^{7}$

\section{Factor 3: 1974 Sales Volume}

Sales of less than $\$ 50,000$ in the aggregate accounted for the largest percentage of firms for size-types I, II, III and IV, and second largest in size-type V. Size-type I had the largest percentage of firms (57.3 percent) with less than $\$ 50,000$ sales, and size-type $V$ had the largest percentage exceeding sales of $\$ 300,000$. The weighted mean on sales by size-type showed sales to increase with size.

\footnotetext{
${ }^{7}$ The weighted mean was calculated to summarize the data in order to determine if a trend existed.
} 


\section{Factor 4: Average Monthly Inventory Purchases}

Average monthly inventory purchases of the business firms tended to increase as size increased. Size-types I and II (less than 1,200 population) were similar in percentage distribution, with about three-fourths of the monthly inventory purchases falling in the interval between $\$ 500$ and $\$ 16,000$. In size-types III, IV and $\mathrm{V}$, the average percentages showed a higher percentage in the higher dollar categories (Table 10).

\section{Factor 5: Average Monthly Business Expenses}

Monthly business expenses of the firms were grouped in ten class intervals (Table 11). The largest percentage of the firms in each size-type central place reported monthly business expenses less than $\$ 1,000$; however, as the size of the central place increased, the percentage of firms with expenses greater than $\$ 1,000$ per month also increased. The increase in the number of firms reporting monthly business expenses greater than $\$ 8,999$ and the weighted mean further indicated that as the size of the central places increased, monthly business expenses of the firms also increased with the exception of size-type IV central place businesses.

TABLE 8. Total assets of business firms by percentage and size-type of central place

\begin{tabular}{lrrrrr}
\hline \hline & \multicolumn{5}{c}{ Size-Type } \\
\cline { 2 - 6 } Assets Intervals & I & II & III & IV & V \\
\hline Less than $\$ 5,000$ & 9.1 & 8.2 & 4.8 & 8.1 & 2.4 \\
$\$ 5,000-\$ 9,999$ & 15.5 & 5.0 & 2.9 & 9.0 & 3.2 \\
$\$ 10,000-\$ 14,999$ & 12.7 & 13.5 & 7.7 & 7.3 & 8.0 \\
$\$ 15,000-\$ 19,999$ & 10.0 & 10.1 & 10.6 & 4.5 & 7.2 \\
$\$ 20,000-\$ 24,999$ & 10.0 & 6.7 & 8.7 & 9.0 & 10.4 \\
$\$ 25,000-\$ 49,999$ & 10.7 & 13.5 & 13.4 & 12.6 & 13.6 \\
$\$ 50,000-\$ 74,999$ & 13.6 & 10.1 & 12.5 & 16.2 & 13.6 \\
$\$ 75,000-\$ 99,999$ & 8.3 & 8.4 & 8.7 & 8.1 & 6.4 \\
$\$ 100,000-\$ 124,999$ & 1.8 & 5.9 & 7.7 & 6.3 & 4.0 \\
$\$ 125,000$ or more & 8.3 & 18.6 & 23.0 & 18.9 & 31.2 \\
Total & 100.0 & 100.0 & 100.0 & 100.0 & 100.0 \\
Weighted mean & $\$ 102,431$ & $\$ 198,601$ & $\$ 241,874$ & $\$ 203,918$ & $\$ 309,399$ \\
\hline
\end{tabular}


TABLE 9. 1974 sales volume of business firms by percentage and size-type of central place

\begin{tabular}{lrrrrr}
\hline \hline & \multicolumn{5}{c}{ Size-Type } \\
\cline { 2 - 6 } Sales Volume Interval & \multicolumn{1}{c}{ I } & II & III & IV & V \\
\hline Less than \$50,000 & 57.3 & 39.0 & 26.9 & 27.2 & 24.8 \\
$\$ 50,000-\$ 99,999$ & 16.3 & 15.3 & 18.3 & 19.1 & 17.6 \\
$\$ 100,000-\$ 149,999$ & 6.4 & 13.6 & 12.5 & 14.5 & 8.0 \\
$\$ 150,000-\$ 199,999$ & 6.4 & 5.9 & 7.7 & 10.9 & 12.8 \\
$\$ 200,000-\$ 249,999$ & 1.8 & 9.3 & 14.4 & 5.5 & 4.8 \\
$\$ 250,000-\$ 299,999$ & 0.0 & 5.9 & 1.9 & 5.5 & 5.6 \\
$\$ 300,000$ or more & 11.8 & 11.0 & 18.3 & 17.3 & 26.4 \\
Total & 100.0 & 100.0 & 100.0 & 100.0 & 100.0 \\
Weighted mean & $\$ 125,409$ & $\$ 156,313$ & $\$ 192,067$ & $\$ 196,227$ & $\$ 246,759$ \\
\hline
\end{tabular}

TABLE 10. Average monthly inventory purchases of business firms by percentage and size-type of central place

\begin{tabular}{lrrrrr}
\hline \hline \multirow{2}{*}{$\begin{array}{c}\text { Monthly } \\
\text { Inventory Purchases }\end{array}$} & \multicolumn{5}{c}{ Size-Type } \\
\cline { 2 - 6 } & \multicolumn{1}{c}{ I } & II & III & IV & V \\
\hline Less than $\$ 250$ & 3.8 & 1.8 & 0.9 & 1.9 & 3.2 \\
$\$ 250-\$ 499$ & 7.6 & 3.6 & 0.9 & 6.4 & 1.6 \\
$\$ 500-\$ 999$ & 10.5 & 14.4 & 7.7 & 6.4 & 1.6 \\
$\$ 1,000-\$ 1,999$ & 14.3 & 11.8 & 13.5 & 10.2 & 12.0 \\
$\$ 2,000-\$ 3,999$ & 23.8 & 14.4 & 15.4 & 14.8 & 12.0 \\
$\$ 4,000-\$ 7,999$ & 10.5 & 17.1 & 21.2 & 20.4 & 20.0 \\
$\$ 8,000-\$ 15,999$ & 16.1 & 19.8 & 15.4 & 20.4 & 28.8 \\
$\$ 16,000-\$ 31,999$ & 7.6 & 7.2 & 15.4 & 9.3 & 10.4 \\
$\$ 32,000-\$ 63,999$ & 2.9 & 5.4 & 4.8 & 7.4 & 4.8 \\
$\$ 64,000$ or more & 2.9 & 4.5 & 4.8 & 2.8 & 5.6 \\
Total & 100.0 & 100.0 & 100.0 & 100.0 & 100.0 \\
Weighted mean & $\$ 9,611$ & $\$ 12,876$ & $\$ 14,552$ & $\$ 12,838$ & $\$ 15,505$ \\
& & & & & \\
\hline
\end{tabular}


TABLE 11. Average monthly business expenses of business firms by percentage and size-type of central place

\begin{tabular}{crrrrr}
\hline \hline $\begin{array}{c}\text { Monthly Business } \\
\text { Expense }\end{array}$ & \multicolumn{5}{c}{ Size-Type } \\
\cline { 2 - 6 } & I & II & III & IV & V \\
\hline Less than \$1,000 & 71.0 & 51.4 & 39.4 & 34.6 & 24.0 \\
$\$ 1,000-\$ 1,999$ & 7.9 & 18.9 & 18.3 & 16.8 & 16.8 \\
$\$ 2,000-\$ 2,999$ & 6.8 & 8.1 & 9.6 & 14.9 & 16.8 \\
$\$ 3,000-\$ 3,999$ & 5.8 & 3.6 & 8.7 & 6.5 & 9.6 \\
$\$ 4,000-\$ 4,999$ & 1.9 & 4.5 & 2.9 & 4.7 & 8.0 \\
$\$ 5,000-\$ 5,999$ & 0.9 & 2.7 & 6.7 & 5.6 & 6.4 \\
$\$ 6,000-\$ 6,999$ & 0.9 & 0.0 & 0.0 & 2.8 & 3.2 \\
$\$ 7,000-\$ 7,999$ & 0.9 & 1.8 & 1.9 & 1.9 & 0.0 \\
$\$ 8,000-\$ 8,999$ & 0.0 & 0.9 & 0.9 & 2.8 & 0.0 \\
$\$ 9,000$ or more & 3.9 & 8.1 & 11.6 & 9.4 & 15.2 \\
Total & 100.0 & 100.0 & 100.0 & 100.0 & 100.0 \\
Weighted mean & $\$ 2,472$ & $\$ 4,553$ & $\$ 6,108$ & $\$ 5,359$ & $\$ 7,388$ \\
\hline
\end{tabular}

\section{Factor 6: Total Liabilities}

In general, liabilities for all retail business firms were low. Even in the largest size-type central places, 47.2 percent of the firms reported liabilities of less than $\$ 5,000$. The lowest was found in the most rural and small size-type central places with population less than 400 (Table 12). The business firms with liabilities greater than $\$ 20,000$ varied from 9 percent in size-type I central places to 30.4 percent in size-type $\mathrm{V}$. The weighted mean indicated further that as the interval size of the central places increased, total liabilities increased.

\section{Factor 7: Mean Asset to Liability Ratio}

The highest mean ratio of assets to liabilities of the business firms' ratios were found in size-type II and size-type III central places (Table 13). Although size-type $\mathrm{V}$ central place firms had a slightly higher ratio than size-type $\mathrm{I}$, on the average, the more rural central place businesses tended to have higher ratios.

\section{Factor 8: Average Age of Business Firms}

The average age of the business firms indicated that the firms in rural central places tended to be, on the average, older than the businesses in the urban central places (Table 14). 
TABLE 12. Total liabilities of business firms by percentage and size-type of central place

\begin{tabular}{lrrrrr}
\hline \hline & \multicolumn{5}{c}{ Size-Type } \\
\cline { 2 - 6 } Liabilities & \multicolumn{1}{c}{ I } & II & III & IV & V \\
\hline Less than $\$ 5,000$ & 76.4 & 68.6 & 56.8 & 63.1 & 47.2 \\
$\$ 5,000-\$ 9,999$ & 6.4 & 6.8 & 9.6 & 8.1 & 9.6 \\
$\$ 10,000-\$ 14,999$ & 3.7 & 3.4 & 10.6 & 6.3 & 8.0 \\
$\$ 15,000-\$ 19,999$ & 4.5 & 5.9 & 5.8 & 4.5 & 4.8 \\
$\$ 20,000-\$ 24,999$ & 0.9 & 2.6 & 2.9 & 1.8 & 8.0 \\
$\$ 25,000-\$ 49,999$ & 4.5 & 4.2 & 3.8 & 6.3 & 9.6 \\
$\$ 50,000-\$ 74,999$ & 0.0 & 3.4 & 2.9 & 2.7 & 3.2 \\
$\$ 75,000-\$ 99,999$ & 0.9 & 2.6 & 3.8 & 1.8 & 3.2 \\
$\$ 100,000-\$ 124,999$ & 0.9 & 0.8 & 0.9 & 0.0 & 1.6 \\
$\$ 125,000$ or more & 1.8 & 1.7 & 2.9 & 5.4 & 4.8 \\
Total & 100.0 & 100.0 & 100.0 & 100.0 & 100.0 \\
Weighted mean & $\$ 11,236$ & $\$ 14,754$ & $\$ 18,956$ & $\$ 21,310$ & $\$ 25,964$ \\
\hline
\end{tabular}

TABLE 13. Ratio of mean assets to liability for business firms by size-type of central place

\begin{tabular}{cccccc}
\hline \hline & \multicolumn{5}{c}{ Size-Type } \\
\cline { 2 - 6 } & I & II & III & IV & V \\
\hline Ratio & $10.2: 1$ & $13.9: 1$ & $12.9: 1$ & $8.3: 1$ & $10.6: 1$ \\
\hline
\end{tabular}

TABLE 14. Average age of business firms by years and size-type of central place

\begin{tabular}{lccccc}
\hline \hline & \multicolumn{5}{c}{ Size-Type } \\
\cline { 2 - 6 } & I & II & III & IV & V \\
\hline Years in business & 32.3 & 27.6 & 17.4 & 19.1 & 12.8 \\
\hline
\end{tabular}




\section{Factor 9: Average Number of Full-time Employees}

The urban central place firms tended to have more full-time employees than did the rural firms (Table 15).

\section{Factor 10: Form of Organization}

The largest percentage of businesses in all five size-type central places were operated as proprietorships. The percentage of partnership business firms was greatest in the rural central places. Corporations were found more often in the urban central places.

\section{Factor 11: Building Ownership}

More than 50 percent of the business firms in all five size-types reported owning the building in which their businesses operated (Table 17). The rural central place firms tended to own their buildings more often thar: did the urban central place firms.

\section{Factor 12: Credit Sales}

The majority of business firms in all five size-types of central places provided credit to their customers (Table 18). The rural firms provided credit to their customers slightly more often than did the urban firms.

TABLE 15. Average number of full-time employees of business firms by size-type of central place

\begin{tabular}{lccccc}
\hline \hline & \multicolumn{5}{c}{ Size-Type } \\
\cline { 2 - 6 } & I & II & III & IV & V \\
\hline No. of employees & 4.3 & 4.3 & 4.4 & 5.2 & 10.7 \\
\hline
\end{tabular}

TABLE 16. Forms of organization of business firms by percentage and size-type of central place

\begin{tabular}{lrrrrr}
\hline \hline & \multicolumn{5}{c}{ Size-Type } \\
\cline { 2 - 6 } & \multicolumn{1}{c}{ I } & II & III & IV & V \\
\hline Proprietorships & 83.0 & 77.3 & 61.5 & 63.9 & 68.0 \\
Partnerships & 8.9 & 9.2 & 10.6 & 8.7 & 5.6 \\
Corporations & 8.1 & 13.5 & 27.9 & 27.4 & 26.4 \\
& & & & & \\
\hline
\end{tabular}


TABLE 17. Percentage of business firms owning their building by size-type of central place

\begin{tabular}{cccccc}
\hline \hline \multicolumn{6}{c}{ Size-Type } \\
\cline { 2 - 6 } & I & II & III & IV & V \\
\hline 77.6 & 66.4 & 58.6 & 51.3 & 58.4 \\
\hline
\end{tabular}

TABLE 18. Percentage of business firms which provided credit sales by size-type of central place

\begin{tabular}{cccccc}
\hline \hline \multicolumn{6}{c}{ Size-Type } \\
\cline { 2 - 6 } & I & II & III & IV & V \\
\hline 66.9 & 72.2 & 65.4 & 69.3 & 61.9 \\
\hline
\end{tabular}

\section{Factor 13: Industry Characteristics}

As reported earlier, selected indicators reflecting economic development were used in selection of the sample counties. Size-types I to IV were found to be more characteristic of agricultural and mining. Size-type central places were most representative of the industrial counties.

\section{MULTIPLE REGRESSION ANALYSIS}

Multiple regression equations were used to determine the relationship of the thirteen independent variable (factors) to one another and to two dependent variables $^{8}-(1)$ the percent of monthly inventory purchases externally financed and (2) the percent of business expansion expenses externally financed since 1960. These two variables most accurately reflect the firms' dependence on credit. Ten of the thirteen factors hypothesized to be related to the extent of external financing were found to be statistically significant at the .10 or better confidence level (Tables 19 and 20).

\footnotetext{
${ }^{8}$ The independent variables used were: $X_{1}$ business classification, $X_{2}$ total assets, $X_{3}$ total 1974 sales, $X_{4}$ age of business, $X_{5}$ average monthly business expenses, $X_{6}$ average monthly inventory purchases, $X_{7}$ total liabilities, $X_{8}$ ratio of assets to liabilities, $X_{9}$ number of full-time employees, $X_{10}$ form of organization, $X_{11}$ building ownership, $X_{12}$ credit sales, $X_{13}$ county industry characteristics. $X_{1}, X_{10}, X_{11}, X_{12}$ and $X_{13}$ are classification variables and were entered as dummy variables.
} 


\section{Percent of Monthly Inventory Purchases Externally Financed- Dependent Variable 1.}

The initial regression equation (percent of monthly inventory purchases externally financed) showed that all thirteen factors combined explained almost 30 percent of the variance in monthly inventory purchases $\left(R^{2}=.29922\right)$. Probably the $R^{2}$ value would have been higher with the addition of more variables. Five of the independent factors were found to have significant $b$ values at the .01 level or higher. They were: classification of business firms, 1974 sales, total liabilities, ratio of assets to liabilities, and county industry characteristics. Two factors found to be significant at the .05 level were average monthly inventory purchases and number of full-time employees (Table 19).

The analysis of the extent to which firms externally financed their inventory purchases uncovered several significant relationships. First, all business classifications of retail firms in rural central places tended to externally finance their inventory purchases less often than urban central places. Second, as the volume of sales and inventory purchases increased, dependence on external financing increased. Third, urban firms used credit more frequently, perhaps reflecting more experience with debt. Fourth, the rural firms' higher ratio of assets to liabilities suggests a preference for a more solvent position. Fifth, the industry characteristic of the county influenced the amount of inventory externally financed, with the firms in industrial counties borrowing substantially more than those in the other types of counties.

In general, one may conclude that rural entrepreneurs borrowed less for inventory purchases due to the class of business; the smaller size of firms as reflected by volume of sales; a preference for remaining out of debt as reflected by higher asset to liability ratios; and the industry characteristics of their location.

\section{Percent of Business Expansion Costs Externally \\ Financed Since 1960-Dependent Variable 2}

Use of credit for business expansion was regressed using the same thirteen variables as for the equation with inventory purchases. Together, they explained 29 percent of the variance of the dependent variable. Five variables were found to be statistically significant at the .01 level. They were 1974 sales volume, age of business, ratio of assets to liabilities, form of organization, and county industry characteristics. One factor, building ownership, was found to be significant at the .10 level (Table 20).

Six variables partially explained why business firms in rural central places externally financed business expansion expenses to less extent than did the urban firms. First, sales and form of organization indicated that larger business firms externally financed more often. Second, age of a firm was negatively correlated with use of credit for capital expansion, the older a firm, the less its dependency on credit. Third, as the ratio of assets to liabilities increased, there was a corresponding decrease in dependency on credit for capital expansion. Fourth, the retail firms in the more urbanized counties utilized credit for capital expansion more frequently than firms in the rural counties. Fifth, the rural firms tended to have a higher degree of ownership of their buildings. 
TABLE 19. Significant independent variables as related to external financed inventory purchases

\section{Independent Variable}

Prob. $b=0$

b Value
$X_{1}$ Business classification*

$x_{3}$ Total 1974 sales

$X_{6}$ Average monthly inventory purchases

$x_{7}$ Total liabilities

$X_{8}$ Ratio of assets to liabilities

$X_{9}$ Number of full-time employees

$\mathrm{X}_{13}$ County type

$\begin{array}{ccc}.0001 & \mathrm{X}_{1 \mathrm{~A}}-8.713 \\ .0002 & .000024 \\ .0244 & .00039 \\ .0001 & .0052 \\ .0040 & & .1398 \\ .0126 & & .1312 \\ .0001 & \mathrm{X}_{13 \mathrm{~A}} & 18.995 \\ & \mathrm{X}_{13 \mathrm{~B}} & 1.830\end{array}$

$R^{2}=.299$

${ }^{*} \mathrm{X}_{1 \mathrm{~A}}$ businesses more characteristic of small (rural) places; $\mathrm{X}_{1 \mathrm{~B}}$ businesses more characteristic of larger (urban) places; $X_{13}$ industrial classification counties; $X_{13 B}$ agricultural counties; and $X_{13}$ mining counties. $X_{1 B}$ and $X_{13 C}$ were entered as zero.

TABLE 20. Variables found significant and their respective $b$ values

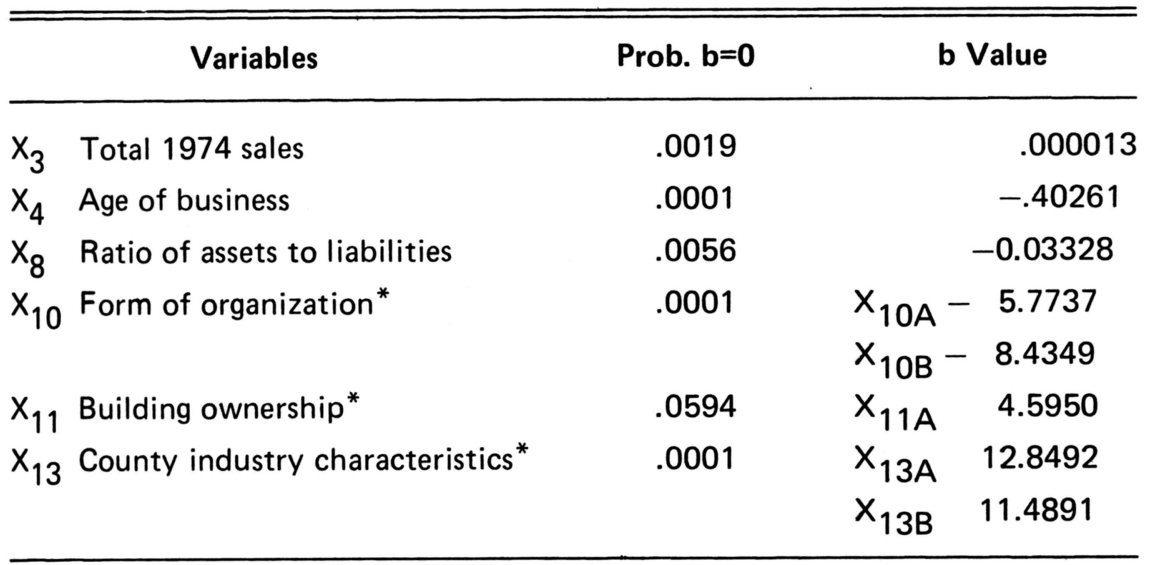

$\mathrm{R}^{2}=.2903$

${ }^{*} X_{10 A}=$ proprietorships, $X_{10 B}=$ partnerships; $X_{10 C}=$ corporations, $X_{11 A}=$ firm owned building; $X_{11 B}=$ building not owned by firm; $X_{13 A}=$ industrial counties; $X_{13 B}=$ agricultural counties; $X_{13 C}=$ mining counties. $X_{10 C}, X_{11 B}$ and $X_{13 C}$ were entered at zero. 


\section{REGIONAL DIFFERENCES EXPLAINED BY ENVIRONMENTAL FACTORS WHICH INFLUENCE RURAL ENTREPRENEURS' USE OF CREDIT}

The statistical analysis indicated that regional differences were affecting the business firms' dependence on credit, but these differences were not explained by regression analysis. Since all conclusions could not be obtained from the statistical data, it was necessary to consider the factor of social environment and its effect on rural entrepreneurs' use of credit. As was stated earlier, during the course of the interviews it was apparent that the attitudes of the entrepreneurs toward credit varied depending upon the region or location; therefore, the influence of attitudinal environment deserves some attention. The mining regions of Logan and Mingo counties are considered to be highly characteristic of the "ruralized mountain culture." Roane and Preston counties, where agriculture is important, reflect the attitudes and value patterns of farm areas. How the attitudes of rural people differ from their urban counterparts has been effectively explained in rural sociological studies $(14 ; 21 ; 18 ; 8)$.

Rural people have been generally recognized as more conservative in their attitudes toward the use of credit. Indications point to a higher degree of risk aversion in the mining and farming rural areas of West Virginia than is generally found in other rural areas of the United States. During the interviews, many businessmen indicated with pride that they were not in debt. They said, "today's younger generation doesn't understand the value of money because it is too easy to borrow." Many said, "I don't owe a penny to nobody and haven't in twenty years."

The existence of risk aversion and social stigma against debt was shown by a study conducted by Marshall University in 1968 (12). The lack of knowledge of basic financial principles and lack of aggressive drive on the part of business operators were the major reasons cited by the study for the non-use of credit by firms. Capital rationing by financial institutions was not found to be the problem, so the author recommended an educational program to provide a more widespread understanding of the use of credit and credit facilities.

Another study determined that the unwillingness of Tennessee farmers to accept credit was having an effect on their ability to compete in modern farming. The study suggested that this attitude toward credit was causing Tennessee's agriculture to develop at a slower rate than the national norm (1). The attitude of debt avoidance had been determined to be only one factor that influences farmers' use of credit. 


\section{BIBLIOGRAPHY}

1. Barnett, Ralph, Hopkins, Robert J., and Snell, James G. 1972. Attitude of Tennessee farmers toward credit. Tennessee Agr. Expt. Sta. Bull. 497, p. 2.

2. Beal, George M., Bohlen, Joe M., and Warland, Res. H. 1968. Rural value-orientations and farm-policy positions and actions. lowa Agr. and Home Econ. Expt. Sta. Bull. 561, pp. 226-39.

3. Berry, Brian J. L. and Garrison, William L. 1958. A note on central place theory and the range of a good. Economic Geography XXXIV:304-11.

4. Brunn, Stanley David. 1968. Changes in the service structure of rural trade centers. Rural Sociol. XXXIII:200-06.

5. Colyer, Dale K. Risk and uncertainty. 1975. West Virginia University, Unpublished mimeo., 8 pp.

6. Edwards, Clark, Coltrane, Robert, and Daberkow, Stan. 1971. Regional variations in economic growth and development with emphasis on rural areas. Agr. Econ. Rept. 205, Economic Research Service, USDA.

7. Gross, Harry. 1969. Financing for small-and medium-sized businesses. Englewood Cliffs, N.J.: Prentice-Hall, Inc.

8. Hayes, A. W. 1929. Rural sociology. New York: Longmans, Green and Co.

9. Hollander, Edwin P. 1971. Principles and methods of social psychology, Oxford University Press.

10. Kaplan, Abraham D. 1948. Small business-Its place and problems. New York: McGrawHill Book Co., Inc.

11. Knight, Frank H. 1921. Risk, uncertainty and profit. Boston: The Riverside Press.

12. Marshall University. 1962. New small business in a redevelopment coal area in West Virginia, pp. 122-23. (Prepared for Small Business Administration.)

13. Nesius, Ernest J. and Thang, Bui Cong. 1976. Various data on West Virginia counties. Division of Resource Management, West Virginia University.

14. Photiadis, John. 1972. Community size and social attributes in West Virginia, pp. 5-32. Appalachian Center Res. Rept. No. 5, West Virginia University.

15. Proxmire, William. 1964. Can small business survive. Chicago: H. Regency.

16. Robinson, Roland I. 1966. Financing the dynamic small firm problems of promotion, survival and growth. Belmont, Cal.: Wadsworth Publishing Co.

17. Rogers, Dorothy. 1972. The psychology of adolescence. 2nd ed. New York: Meredith Corp.

18. Sims, N. L. 1928, Elements of rural sociology. New York: Thomas Y. Corwell Co.

19. White, L. T. 1971. Strengthening small business management, ed. Joseph C. Schabacker. Washington: U. S. Government Printing Office.

20. United States Congress, House of Representatives, Select Committee on Small Business, 1967. Small business in smaller cities and towns, Hearings before Subcommittee on Urban Areas, 90th Congress, 1st Sess. on H. 53. Washington: U. S. Government Printing Office.

21. United States Small Business Administration. 1973. Starting and managing a small business. Washington: U. S. Government Printing Office. 


\section{APPENDIX}

\section{QUESTIONNAIRE USED FOR FIELD STUDY}

\section{CONFIDENTIAL}

Department of Resource Management

West Virginia University

Credit Availability Questionnaire

I. Retail Business

1. Age of Business

2. Form of Organization of Business:

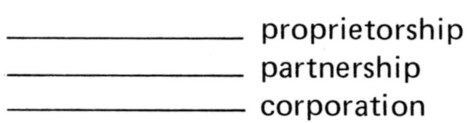

3. Does the business firm own the building which it operates?

$$
\text { Yes No }
$$

4. Does the owner rent or lease any of the equipment or property used in the operation of the business?

Yes No

Note to Enumerator: Leasing of equipment is a form of credit provided by equipment dealers.

Be sure to include this in Part II.

5. Does this business sell for credit? (If no, skip No. 6)

$$
\text { Yes No }
$$

6. If answer to No. 5 is yes, who provides financing for such sales?

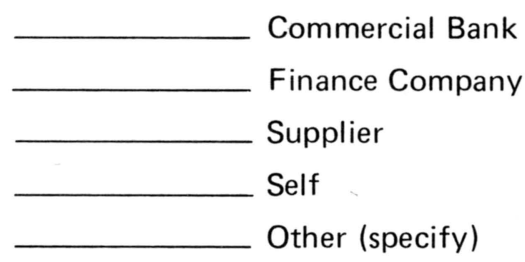


II. Borrowed Funds

Since 1960 has this business obtained funds - financing - credit, from:

$$
\text { Yes }
$$

No

1. A commercial bank

2. Wholesale supplier (most recent) (1974) (2 parts)

3. Equipment supplier (dealer)

4. Stockholders

5. Equipment leaser

6. Friends or relatives

7. Small business administration

8. Other (specify)

\begin{tabular}{|l|l|l|l|l|l|l|l|l|l|l|}
\hline \hline Source & $\begin{array}{c}\text { Distance } \\
\text { Source } \\
\text { Location }\end{array}$ & $\begin{array}{c}\text { Year } \\
\text { Date }\end{array}$ & $\begin{array}{c}\text { Full } \\
\text { Amount }\end{array}$ & Amount & $\begin{array}{c}\text { (Simple) } \\
\text { Annual } \\
\text { Interest }\end{array}$ & $\begin{array}{c}\text { Repayment } \\
\text { Method }\end{array}$ & Collateral & Use & Length & Required \\
\hline & & & & & & & & \\
\hline & & & & & & & & & & \\
\hline & & & & & & & & & & \\
\hline
\end{tabular}


IIb. Self-Finance

19. a. What percent of your yearly inventory purchases are self-financed?

b. What percent of your yearly business operational expenses are self-financed?

c. Since 1960 what percent of your business expansion, or business improvement expenses were self-financed?

20. Do you have a revolving account (not from credit sources) from which you:
a. Finance inventory purchases?
No
b. Pay business expenses?
Yes
No
c. Finance business expansion of business improvement expenses?

21. Answer to $2 a, b, c$, is yes

a. What is the amount of funds that you maintain monthly for: Inventory purchases?

Business expenses?

Investments in fixed assets?

22. Are these funds maintained in a checking account?

$$
\text { Yes No }
$$

If no, where?

23. If answer to question No. 4 is yes, what amount of interest payments are foregone by maintaining these balances? 


\section{Refusal of Funds}

Since 1960 have you attempted to obtain funds - financing - credit from any of these sources and had the application denied?

Yes

Questions $24-33$ )

1. A commercial bank

2. Wholesale supplier

3. Equipment supplier

4. Stockholders

5. Equipment leaser

6. Friends or relatives

7. Small business administration

8. Other (specify)

$\tilde{\omega}$

\begin{tabular}{|l|l|l|l|l|l|l|l|}
\hline \hline Source & $\begin{array}{c}\text { Distance } \\
\text { Source } \\
\text { Location }\end{array}$ & $\begin{array}{c}\text { Date } \\
\text { Year }\end{array}$ & $\begin{array}{c}\text { Proposed } \\
\text { Interest }\end{array}$ & $\begin{array}{c}\text { Proposed } \\
\text { Collateral }\end{array}$ & $\begin{array}{c}\text { Proposed } \\
\text { Use }\end{array}$ & $\begin{array}{c}\text { Proposed } \\
\text { Length }\end{array}$ & $\begin{array}{c}\text { Proposed } \\
\text { Repayment } \\
\text { Method }\end{array}$ \\
\hline & & & & & & & \\
\hline & & & & & & & \\
\hline & & & & & & & \\
\hline
\end{tabular}


IV. Business Statistics $-{ }^{*}$ (White Cards) ${ }^{*}$ Indicates the use of white cards 28. How many people does your business employ?

No. 1

29. a. Value of firm's assets?

29. b. Fixed assets \% total assets?

Current assets \% total assets?

Fixed assets are composed of such things as land, buildings and equipment. Current assets are assets in the form of cash and other assets which in the normal operation of business in short-time intervals will be converted into cash. Examples are demand deposits, inventories and Accounts Receivable

No. 2

30. Amount of firm's total liabilities?

No. 3

31. Amount of total 1974 sales?

32. If you could send a message to suppliers of credit from which you borrow what are some recommendations you would make for improvement?

33. Would you be willing to respond to future questions of this type at a later date by mail or personal visit?

Yes

No

Information to be supplied by Enumerator

Enumerator:

County:

Place: Size:

Name of Business:

Date of Interview:

Position of Person Interviewed Relative to the Business:

Type of Business: 
Blank Page in Original Bulletin 
Blank Page in Original Bulletin 